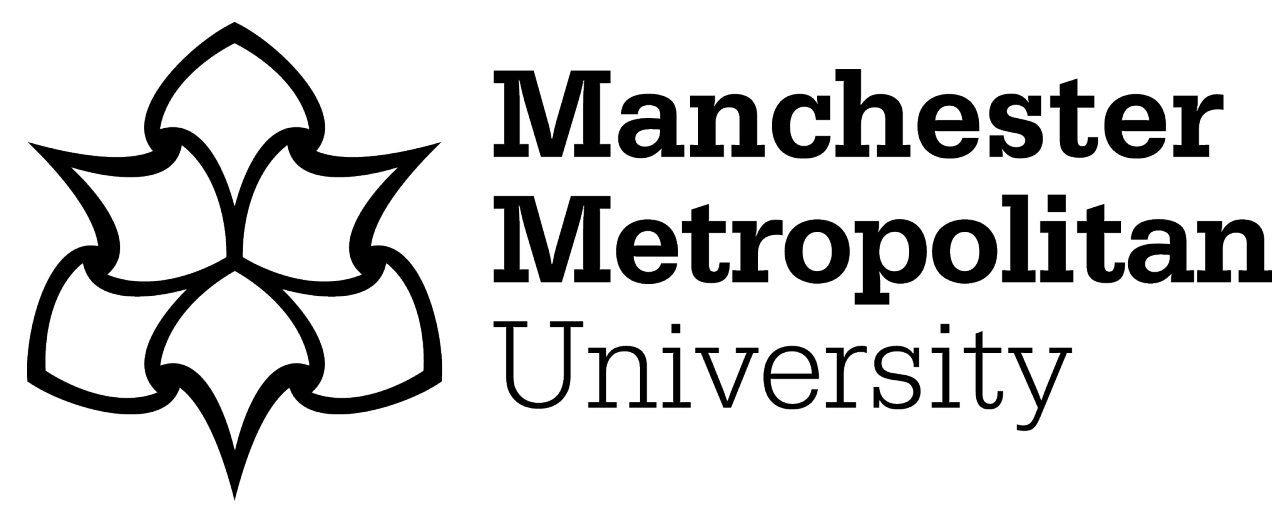

Bresnen, Mike ORCID logoORCID: https://orcid.org/0000-0002-3295-8235, Hodgson, Damian, Bailey, Simon, Hyde, Paula and Hassard, John (2017) Management knowledge and learning in the UK healthcare context: change and continuity. [Conference or Workshop Item]

Downloaded from: https://e-space.mmu.ac.uk/624932/

Version: Accepted Version

Publisher: Academy of Management

DOI: https://doi.org/10.5465/ambpp.2016.128

Please cite the published version 


\title{
MANAGEMENT KNOWLEDGE AND LEARNING IN THE UK HEALTHCARE CONTEXT: CHANGE AND CONTINUITY
}

\author{
Mike Bresnen, Damian Hodgson, Simon Bailey, Paula Hyde and John Hassard \\ Alliance Manchester Business School, University of Manchester, UK
}

Pre-publication version of conference paper submitted for publication in: John Humphreys (Ed.), Proceedings of the Seventy-sixth Annual Meeting of the Academy of Management. Online ISSN: 2151-6561

\section{Introduction: transformations in healthcare management}

Change and innovation have been profound in recent years in many healthcare institutions worldwide. In the UK public healthcare system, pressures have been placed on the health service to improve efficiency and cost effectiveness as well as the organization and delivery of patient care (Dopson et al., 2008; Ferlie et al., 2005). Principal amongst the features of UK healthcare that the spotlight has focused upon have been managers themselves (Hyde et al., 2016; Learmonth, 2005). A series of government policies and institutional initiatives have, over the last decade, challenged existing approaches to management and questioned the value of existing managerial capacity, capabilities and skills (King's Fund, 2011). Coinciding in the last five years with major cuts to middle management in the UK's National Health Service (NHS) (Whitehead et al., 2010), a new clarion call has emerged that disparagingly contrasts healthcare management with the 'leadership' purportedly required to improve healthcare delivery (Bresnen et al., 2015; O’Reilly \& Reed, 2011).

Against this backdrop, there has been much closer forensic examination of the nature of managerial work in healthcare, its professional basis and underpinning body of knowledge, and the factors enabling and inhibiting the mobilization and exploitation of different forms of management knowledge (Ferlie et al., 2012). For some time, healthcare management has been perceived as 'lagging behind' developments in management practice, and this negative profiling has meant greater demands on healthcare managers to mobilize 'leading edge' management thinking more effectively (Fischer et al., 2015; Pollitt, 2013). However, there is also a long-standing recognition that such thinking does not easily, or even necessarily, translate into a healthcare context; and that there are major institutional and organizational barriers that inhibit flows of managerial knowledge and learning within the sector (Dopson et al., 2008; Ferlie et al., 2005, 2015).

As in many other sectors, management within healthcare has struggled to develop a distinct knowledge base and clear-cut professional identity (Currie, 1997; Currie \& Proctor, 2005). In part, this is due to the distinctiveness of healthcare that makes it difficult to apply generic management knowledge (Buchanan, 2013; Currie \& Suhomlinova, 2006). However, it is also due to the highly differentiated nature of healthcare organizations (Hartley \& Benington, 2006; Willem \& Buelens, 2006) and the distributed nature of their internal management (Buchanan et al., 2007). This shapes managerial practice in complex ways and inhibits the spread of management practices and knowledge. It also means that any management initiatives inevitably cut across the interests of clinical and other professional/occupational communities of practice (Currie, 1997; Fulop \& Mark, 2013; Nicolini et al., 2008; Noordegraaf \& Van Der Meulen, 2008). Although a lot is known about how this affects relationships with clinicians (Currie, 1997, 2006; Davies \& Harrison 2003; Hyde 
2010), comparatively little is known about how managers in healthcare actually mobilize and utilize management knowledge and what this means for management learning (Ferlie et al., 2012). While some types of codified systems of knowledge do appear to influence management thinking and action (Ferlie et al., 2015; Fischer et al., 2015), evidence of their impact on practice is often patchy, implicit and challenged (Hyde et al., 2016; McCann et al., 2015).

What is needed therefore is more in-depth research that not only examines how managers in healthcare access, acquire and apply their knowledge and learning, but which is also sensitive to the ways in which different forms of knowledge and learning inter-relate to shape managerial thinking and practice (cf. Cook \& Brown, 1999; Fischer et al., 2015). It is also important to set this in the context of changes occurring at the institutional and organizational level. So, for example, are there any tensions between current changes being promoted in the sector and managers' predispositions to act in particular ways based upon their established knowledge bases and orientations to learning?

\section{Exploring management knowledge and learning in healthcare: a practice-based approach}

Recent thinking about forms of knowledge in healthcare management has followed developments in knowledge management and organizational learning theory by questioning the traditional conception of knowledge as something that is an object or possession that can simply be transferred into practice (e.g. Greenhalgh, 2010; Oborn et al., 2013). Instead, it has embraced approaches that recognize the more dynamic and situated nature of knowing and learning as they occur through (management) practice (Newell et al., 2009; Nicolini, 2011) and as they relate to the social networks and professional communities of practice which managers inhabit (Brown \& Duguid, 2001; Lave \& Wenger, 1991).

This paper takes such a practice-based approach and attempts to distinguish between forms of knowledge and types of learning that are encountered in practice by drawing upon Blackler's (1995) categorization of forms of knowledge. Blackler (1995) identifies five recurrent 'images' of knowledge identified in the literature: that embedded in technologies, rules and procedures; that embodied in the physical skill sets of individuals; that embrained in the intellectual abilities of individuals; that encoded in abstract knowledge and associated tools and techniques; and that encultured in professional norms, values and practices. There is, of course, a good deal of ambiguity in the boundaries between these forms of knowledge. However, as a heuristic, this framework offers a useful way of unraveling some of the complexities of management knowledge and learning in healthcare. It could be argued, for instance, that the main predispositions to knowing/learning (and the resultant tensions that are created) are the result of a simultaneous dependence upon the embodied knowledge of experts and the dominance of routinized processes through which knowledge is embedded (cf. Davies \& Harrison, 2003).

The framework also encapsulates important dimensions of knowledge and learning that are subsumed within these ways of knowing. First, it captures the classic distinction between explicit and tacit forms of (management) knowledge (e.g. Nonaka, 1994), allowing a clear dividing line to be drawn, for example, between more explicit, codified systems of knowledge (such as management tools and techniques) and forms of knowledge that are more dependent on individual action/cognition (such as embodied personal experience). Second, it encompasses a basic distinction between more abstracted forms of learning and learning that is more experiential and situated in practice (Brown \& Duguid, 2001; Carlile, 2004; Cook \& Brown, 1999). 
In what follows, Blackler's knowledge types (with the exception of embrained) are used to highlight sources of management knowledge used by healthcare managers. Importantly, the analysis brings to the fore the context, seeking to explain how and why different sorts of knowledge and learning are drawn upon by managers in different types of healthcare organization and how this might in turn reflect, reinforce or inhibit wider institutional and organizational change.

\section{Research methods}

The research set out to explore the perspectives of three 'clusters' of managerial groups - clinical, general and functional specialists - within three NHS trusts in the same region of the UK. The trusts were selected to represent diverse activities: one general hospital (Acute); one providing mental health and community services (Care); and one providing tertiary care (Specialist). Within each trust/hospital, managers were selected on the basis of a framework that differentiated between the three clusters of managers (see Bresnen et al., 2015). Within each cluster, managers were purposively sampled to represent a range of operational and functional areas. They were selected for interview and observation if they had mid- to senior-level responsibilities.

Semi-structured interviews combined with observation of formal and informal events and meetings (from management meetings to training events) constituted the core methods of data collection. In total, 68 respondents were interviewed (20 at Acute, 25 at Care and 23 at Specialist) and 54 hours of observations were undertaken. All interviews were recorded and transcribed and field notes from direct observations were also captured. Data were coded and analyzed using NVivo software and open coding techniques (Strauss \& Corbin, 1990). Space limitations mean that only a few selected quotes are used here to illustrate summaries of the main findings.

\section{Research findings}

\section{'Encultured' knowledge: Professional norms, values and practices}

"You almost need to like learn little bits of everything ... You need to understand how a nurse rota works and ... when a surgeon goes in to do a complex procedure, broadly what he's (sic) doing, so you can understand the time pressures, how many people are in there, what they're doing ... You're never an expert in anything." (Finance Manager, Specialist)

Of the 68 managers interviewed, most $(42=62 \%)$ came from a clinical or similar professional background ( 5 doctors, 23 nurses, 5 scientists, 7 allied health professionals (AHPs) and 2 social workers). That number included all general managers at the Care trust $(10=83 \%$ of whom were former nurses) and over half of those at the Acute and Specialist trusts (63\% and 56\% respectively). Of the 42, most had at least one relevant medical or nursing professional qualification (the exceptions were the AHPs, social workers and some medical scientists).

Many general managers therefore had a well-developed technical understanding that enabled them to communicate effectively with their teams and to engage with clinicians. Nevertheless, they often still struggled to establish credibility in the eyes of clinicians, and this could often only effectively be achieved through using other strategies that combined their clinical knowledge with interpersonal skills and/or their personal experience as hybrid managers (Burgess \& Currie, 2013). In 
the Specialist and Acute trusts, structural mechanisms and relational skills were important; in the Care trust, where most general managers were experienced nurses, personally embodied clinical knowledge was vital. In both cases, however, the dominant clinical discourse was still difficult to counteract, and forced managers to conform to an appropriate way of thinking (i.e. clinically) if they were to create convincing and credible arguments.

At the same time, financial expertise was also important in defining managerial discourse within the trusts, and what was apparent from those interviewed was how natural and normalized the emphasis on finance had become, and how this shaped perceptions and processes of managerial work. While this internalization of financial management discourse was particularly pronounced amongst general managers and their functional counterparts, it was noticeable too from the interviews how normal and acceptable it had become to clinical managers and their teams.

\section{'Encoded' knowledge: Management tools and techniques}

"We had an all-day event yesterday with the new community teams... about how we can amalgamate and transform these teams. And really what we did in that day was effectively Lean, in the sense that it was value stream mapping ... but it was never packaged as that." (Associate Director, Acute)

Explicit references to established and codified systems of management knowledge, which were consciously drawn upon with an attempt to apply them, were comparatively rare. Clinicians inevitably referred anyway less to management knowledge per se than to the importance of relevant clinical expertise. Functional managers naturally drew upon their own expert knowledge in the routine performance of their work (e.g. accounts, IT protocols). Process mapping or strategic modeling were mentioned by one or two individuals keen to apply what they saw as relevant generic management tools and techniques to make sense of management problems. There were also references made to attempts to apply lean thinking principles to the sector, particularly at the Acute trust. However, where explicit reference was made, as the above quote suggests, the emphasis was not on direct application but in their indirect use to facilitate managerial reflection. Furthermore, such attempts to transform practice invariably exhibited isomorphic tendencies that were reflected in the inward-looking search for best practice from within the sector (cf. McNulty, 2002).

\section{'Embedded' knowledge: Management processes and systems}

"The organization needs you to be able to tick their boxes, so being able to understand their must-dos and their must-haves and their givens, the data stuff-if you can pay attention to that and translate your activity into that in a comprehensible way, that can carry you a long way." (Service Manager, Care)

What came across very strongly in the interviews was the privileging of home grown management (sector, trust) systems and practices that might owe some debt to a wider, more diffuse management knowledge base (particularly related to financial and operations management), but which were predominantly driven by formal, sector-specific requirements. These requirements for monitoring and reporting of levels of care and performance had clear consequences not only for the balance and focus of managerial effort, but also for the primacy attached to situated management knowledge that was embedded in local systems and processes. Moreover, this external institutional 
pressure predisposed the trusts to develop management systems and procedures that were heavily geared towards standardization and formalization of process. It also meant that one of the continuing challenges facing all of the trusts was the tension that existed between 'corporate' attempts to standardize processes and practices and the more localized approaches that managers continued to use in their part of the organization.

\section{'Embodied' knowledge: Experience and experiential learning}

"You can go on management courses till the cows come home, can't you, but you can either manage or you can't, and I think a lot of it does come from experience and your own personality." (Therapies Manager, Acute)

The above quote captures a consistent view that it was experience that really mattered. However, experiential learning was not necessarily associated with a smooth journey that gave managers great opportunities for reflective learning. Many of those interviewed had encountered obstacles in the path to reaching their current position (with jobs being re-defined, re-combined or made open to competitive application). 'Muddling through' also typified a good deal of the learning involved: general and clinical managers, in particular, emphasized the 'trial and error' associated with learning how to do their jobs. This not only reflected the sporadic nature of day to day managerial work, but also the real constraints on managers' time due to the 'normalized intensity' associated with pressures on managers to deliver (McCann et al., 2008). Managerial learning was taking place but it was as much about learning to cope without sufficient time and resources as it was about being able to learn new things.

Social learning also figured highly in accounts given: formally, through mentoring and coaching; and informally, through personal direct observation and conscious role modeling. However, this depended upon opportunities for social interaction and reflection. Where these were limited, it meant a greater reliance on more formal means of passing on knowledge and learning that did not translate so easily and directly into practice (i.e. training courses). Moreover, there were a number of downsides to the over-reliance on the embodied skills of managers and the situated learning taking place within their immediate operational context. Not only did it reinforce localized learning through problem-solving on a management by exception basis, it also created challenges for the organization in externalizing knowledge (cf. Nonaka \& Takeuchi, 1995).

\section{Concluding discussion}

What was perhaps most striking was the degree of consistency across the trusts and managerial groups in how management knowledge and learning processes were approached and made sense of. This was despite there being a good deal of variation in the backgrounds and experience of managers within the study. The above has highlighted in passing some significant differences found between trusts and managerial groups in their orientations to management knowledge. However, what emerged from the study was a fairly consistent set of findings, namely:

- $\quad$ the continued shaping of management knowledge through the dominant discourses of (particularly) clinical expertise and financial management; 
- difficulties of translating and embedding more abstract management knowledge into heath care settings;

- the dominant influence of 'home grown' management knowledge embedded in systems and practices and reinforced through formal training; and

- the importance of individual experience and the personal embodiment of management knowledge

Taking these points together, at one level, the research lends further support to the idea that it can prove difficult to translate and embed more abstract and encoded forms of management knowledge (such as lean thinking) from outside healthcare into the sector (Hyde et al., 2016; McCann et al., 2015; Waring \& Bishop, 2010). However, it contributes further by setting that in the context of the continuing influence (and even strengthening) of more embedded and embodied forms of management knowledge (cf. Blackler, 1995). These are found, respectively, in the management systems and practices devised and enacted locally to respond to institutional reporting requirements; and in the personal experiences and skill sets of managers - particularly so-called 'hybrid' managers (cf. Burgess \& Currie, 2013; Currie \& White, 2012; McGivern et al., 2015). Similarly, while the research confirms the continued shaping of management knowledge through the hegemonic discourse of clinical expertise (e.g. Oborn et al., 2013), it also contributes further by highlighting potential countervailing influences. These include the elaboration of integrative mechanisms and relational capabilities (cf. Owen-Smith et al., 2002); and the power of financial accounting knowledge and practice in management decision-making (cf. Armstrong, 1987).

Overall, the research reported here suggests that the trajectory of change in management within healthcare organizations may be towards a more 'professionalized' view of management qua leadership (O'Reilly \& Reed, 2011). However, what is occurring at the level of management practice hardly supports such ambition. First, there are tensions that exist between, on the one hand, calls for the development and application of more leading-edge (abstract) managerial knowledge on the part of healthcare managers; and, on the other hand, the direction of travel of most knowledge acquisition, training and development by healthcare managers - which tends to emphasize practical solutions and which privileges more situational and experiential forms of learning. Second, it suggests that, in the current context of change in healthcare (at least in the UK), these tensions are exacerbated by the need facing managers to respond to immediate operational demands, giving them much less time and opportunity than they would like to pursue more strategic, reflective thinking or even to take up available training and development opportunities. Overall, this suggests a greater divergence than policy makers and institutional bodies might like to think between the espoused theories surrounding professionalism in management in healthcare and the theories in use of managers faced with the daily agenda of pressing operational demands. Progress may only be possible if these contradictions are recognized, confronted and somehow resolved.

\section{Acknowledgements}

Research reported in this paper was funded by the UK National Institute for Health Research Service Delivery and Organization (NIHR SDO) program (project number 09/1002/29). The views and opinions expressed are those of the authors and do not necessarily reflect those of the SDO program, NIHR, NHS or the Department of Health. 


\section{References}

Armstrong, P. 1987 'The rise of accounting controls in British capitalist enterprises', Accounting, Organizations and Society, 12, 5, 415-436.

Blackler, F. 1995. 'Knowledge, knowledge work and organizations: an overview and interpretation', Organization Studies, 16, 6, 1021-46.

Bresnen, M., P. Hyde, D. Hodgson, S. Bailey and J. Hassard. 2015. 'Leadership talk: from managerialism to leaderism in healthcare after the crash', Leadership, 11, 4, 451-470.

Brown, J. S. and P. Duguid. 2001. 'Knowledge and organization: a social practice perspective', Organization Science, 12, 198-213.

Buchanan, D. 2013. 'Pure plays and hybrids: acute trust management profile and capacity', Journal of Health Services Research \& Policy, 18, 2, 90-97.

Buchanan, D., R. Addicott, L. Fitzgerald, E. Ferlie and J. Baeza, J. 2007. 'Nobody in charge: distributed change agency in healthcare', Human Relations, 60, 7, 1065-1090.

Burgess, N. and G. Currie. 2013. 'The knowledge brokering role of the hybrid middle level manager: the case of healthcare', British Journal of Management, 24, S132-S142.

Carlile, P. 2004. 'Transferring, translating, and transforming: an integrative framework for managing knowledge across boundaries', Organization Science, 15, 5, 555-68.

Cook S., and J. Brown. 1999. 'Bridging epistemologies: the generative dance between organizational knowledge and organizational knowing', Organization Science, 10, 4, 381-400.

Currie, G. 1997. 'Contested Terrain: the incomplete closure of managerialism in the health service', Health Manpower Management, 23, 4, 123-132.

Currie, G. 2006. 'Reluctant but resourceful middle managers: the case of nurses in the NHS', Journal of Nursing Management, 14, 5-12.

Currie, G. and S. Proctor. 2005. 'The antecedents of middle managers' strategic contribution: the case of a professional bureaucracy', Journal of Management Studies, 42, 7, 1325-1356.

Currie, G. and O. Suhomlinova. 2006. 'The impact of institutional forces upon knowledge sharing in the UK NHS: the triumph of professional power and the inconsistency of policy', Public Administration, 84, 1, 1-30.

Currie, G. and L. White. 2012. 'Inter-professional barriers and knowledge brokering in an organizational context: the case of healthcare', Organization Studies, 33, 10, 1333-1361.

Davies, H.T.O. and S. Harrison. 2003. 'Trends in doctor manager relationships', British Medical Journal, 326, 646-649. 
Dopson, S., L. Fitzgerald and E. Ferlie. 2008. 'Understanding change and innovation in healthcare settings: reconceptualizing the active role of context', Journal of Change Management, 8, 3-4, 21331.

Ferlie, E.. T. Crilly and A. Jashapara. 2012. 'Knowledge mobilization in healthcare: a critical review', Social Science and Medicine, 74, 8, 1297-1304.

Ferlie, E., L. Fitzgerald, M. Wood and C. Hawkins. 2005. 'The nonspread of innovations: the mediating role of professionals', Academy of Management Journal, 48, 1, 117-34.

Ferlie, E., J. Ledger, S. Dopson, M.D. Fischer, L. Fitzgerald, G. McGivern and C. Bennett. 2015. 'The political economy of management knowledge: management texts in English healthcare organizations', Public Administration.

Fischer, M.D., S. Dopson, L. Fitzgerald, C. Bennett, E. Ferlie, J. Ledger and G. McGivern. 2015. 'Knowledge leadership: mobilizing management research by becoming the knowledge object', Human Relations.

Fulop, L. and A. Mark. 2013. 'Leading in healthcare - foregrounding context', Leadership, 9, 2, 151-61.

Greenhalgh, T. 2010. 'What is this knowledge that we seek to 'exchange'?', The Millbank Quarterly, 88, 4, 492-499.

Hartley, J. and J. Benington. 2006. 'Copy and paste, or graft and transplant? Knowledge sharing through inter-organizational networks', Public Money and Management, 26, 2, 101-108.

Hyde, P. 2010. 'Changing relationships between health service managers: confrontation, collusion and collaboration', in J. Braithwaite, P. Hyde and C. Pope (eds), Culture and climate in health care organizations. Basingstoke: Palgrave MacMillan, pp. 97-108.

Hyde, P., E. Granter, J. Hassard and L. McCann. 2016. Deconstructing the welfare state: Managing healthcare in the age of reform. London: Routledge

Kings Fund. 2011. The future of leadership and management in the NHS: No More Heroes. London: The Kings Fund.

Lave, J. and E. Wenger. 1991. Situated learning: legitimate peripheral participation. Cambridge: Cambridge University Press.

Learmonth, M. 2005. 'Doing things with words: the case of 'management' and 'administration', Public Administration, 83, 3, 617-637.

McCann, L., J. Morris and J. Hassard. 2008. Normalized intensity: the new labour process of middle management', Journal of Management Studies, 45, 2, 343-371. 
McCann, L., J. Hassard, E. Granter and P. Hyde. 2015. Casting the lean spell: the promotion, dilution and erosion of lean management in the NHS', Human Relations, 68, 10, 1557-1577.

McGivern, G., G. Currie, E. Ferlie, L. Fitzgerald and J. Waring. 2015. 'Hybrid managerprofessionals' identity work: the maintenance and hybridization of professionalism in managerial contexts', Public Administration, 93, 2, 412-432.

McNulty, T. 2002. 'Reengineering as knowledge management: a case of change in UK healthcare', Management Learning, 33, 4, 439-458.

Newell, S., M. Robertson, H. Scarbrough and J. Swan. 2009. Managing knowledge work and innovation. Basingstoke: Palgrave Macmillan.

Nicolini, D. 2011. 'Practice as the site of knowing: insights from the field of telemedicine', Organization Science, 22, 3, 602-620.

Nicolini, D., J. Powell, P. Conville and L. Martinez-Solano. 2008. 'Managing knowledge in the healthcare sector: a review', International Journal of Management Reviews, 10, 3, 245-263.

Nonaka, I. 1994. 'A dynamic theory or organizational knowledge creation', Organization Science, $5,1,14-37$.

Nonaka, I. and I. Takeuchi. 1995. The knowledge creating organization. Oxford: Oxford University Press.

Noordegraaf, M. and M. Van Der Meulen. (2008). 'Professional power play: organizing management in health care', Public Administration, 86, 4, 1055-1069.

Oborn, E., M. Barrett and G. Racko. 2013. 'Knowledge translation in healthcare', Journal of Health Organization and Management, 27, 4, 412-431.

O'Reilly, D. and M. Reed. 2011. 'The grit in the oyster: professionalism, managerialism and leaderism as discourses of UK public services modernization', Organization Studies, 32, 8, 10791101.

Owen-Smith, J., M. Riccaboni, F. Pammolli and W. Powell. 2002. 'A comparison of US and European university-industry relations in the Life Sciences', Management Science, 48, 1, 24-43.

Pollitt, C. 2013. 'The evolving narratives of public management reform', Public Management Review, 15, 6, 899-922.

Strauss, A. and J. Corbin. 1990. Basics of qualitative research: grounded theory procedures and techniques. Newbury Park, CA: Sage.

Waring, J.J. and S. Bishop. 2010 'Lean healthcare: rhetoric, ritual and resistance', Social Science and Medicine, 71, 7, 1332-1340. 
Whitehead, M., B. Hanratty and J. Popay. 2010. 'NHS reform: untried remedies for misdiagnosed problems?', The Lancet, 6763, 10, 231-7.

Willem, A. and M. Buelens. 2006. 'Knowledge sharing in public sector organizations: the effect of organizational characteristics on interdepartmental knowledge sharing', Journal of Public Administration Research and Theory, 17, 4, 581-606. 